\title{
Determination of Salbutamol and Guaifenesin in Mixture Using Zero- Crossing Wavelength Measurement
}

\author{
Entris Sutisna ${ }^{1}$, Farida Fauzia ${ }^{1}$, Ida Musfiroh ${ }^{2}$, Shelvy E. Suherman ${ }^{2}$ \\ ${ }^{1}$ Sekolah Tinggi Farmasi Bandung, Bandung, West Java, Indonesia \\ ${ }^{2}$ Faculty of Pharmacy, Universitas Padjadjaran, Sumedang, West Java, Indonesia
}

\begin{abstract}
A mixture of salbutamol and guaifenesin in syrup was analyzed using zero-crossing wavelength method. $\mathrm{NaOH} 0.1 \mathrm{~N}$ was selected as the solvent. Zero-crossing wavelength of salbutamol is $246.2 \mathrm{~nm}$ and guaifenesin is $270.2 \mathrm{~nm}$. Results showed that the recovery of salbutamol and guaifenesin are $95.96 \%$ and $93.94 \%$, respectively, while the coefficient of variance is $0.995 \%$ for salbutamol and $0.2087 \%$ for guaifenesin. Limit of detection of salbutamol and guaifenesin are $0.05528 \mathrm{ppm}$ and 9.443 ppm, respectively, while limit of quantification are $0.18427 \mathrm{ppm}$ and $31.477 \mathrm{ppm}$. We concluded that this method could be applied to determine salbutamol and guaifenesin in mixture.
\end{abstract}

Keywords: Derivative spectrophotometry, guaifenesin, salbutamol, zero-crossing

\section{Penentuan Salbutamol dan Guaifenesin dalam Campuran Menggunakan Pengukuran Panjang Gelombang Zero-Crossing}

\begin{abstract}
Abstrak
Campuran salbutamol dan guaifenesin dalam sirup dianalisis menggunakan metode panjang gelombang zero-crossing. $\mathrm{NaOH} 0,1 \mathrm{~N}$ dipilih sebagai pelarut. Panjang gelombang zero-crossing salbutamol adalah $246,2 \mathrm{~nm}$ dan $270,2 \mathrm{~nm}$ guaifenesin. Hasil penelitian menunjukkan bahwa \% recovery salbutamol dan guaifenesin adalah $95,96 \%$ dan $93,94 \%$, sedangkan koefisien variasi adalah $0,995 \%$ untuk salbutamol dan $0,2087 \%$ untuk guaifenesin. Batas deteksi salbutamol dan guaifenesin adalah 0,05528 ppm dan 9,443 ppm, sedangkan batas kuantifikasi adalah 0,18427 ppm dan 31,477 ppm. Dapat disimpulkan bahwa metode ini bisa diterapkan untuk menentukan salbutamol dan guaifenesin dalam campuran.
\end{abstract}

Kata kunci: Guaifenesin, salbutamol, spektrofotometri derivatif, zero-crossing

Correspondence: ida musfiroh idamusfiroh@yahoo.com 


\section{Introduction}

Derivative spectrophotometry is a technique based on derivative spectra of a basic, zero-order spectrum. ${ }^{1}$ The results of derivatization of function described a run of absorbance curve is called the derivative spectrum. It has found a wide application in the quantitative chemical analysis. ${ }^{2}$ It can be used for multi component analysis, such as determination of drugs mixtures. ${ }^{3}$

An example of drugs in mixture are salbutamol and guaifenesin in syrup. Salbutamol in sodium hydroxide $(\mathrm{NaOH})$ shows maxima absorption $\left(\lambda_{\max }\right)$ at 295 $\mathrm{nm},{ }^{4}$ while guaifenesin is at $273 \mathrm{~nm} .{ }^{5}$

This paper described application of zero-crossing wavelength ( $\left.\lambda_{\text {zero-crossing }}\right)$ measurement to determine salbutamol and guaifenesin in syrup.

\section{Methods}

Instrument that used was ultraviolet spectrophotometer (Shimadzu 1700) and chemical glasswares. Materials that used was salbutamol and guaifenesin (BFPI), methanol, $\mathrm{HCl} 0.1 \mathrm{~N}, \mathrm{NaOH} 0.1 \mathrm{~N}$.

This research was conducted with raw materials analysis. Raw materials of salbutamol and guaifenesin were analyzed according to Indonesian Pharmacope $5^{\text {th }}$ edition that included solubility test and identification reaction. ${ }^{6}$

Salbutamol and guaifenesin in syrup were analyzed. The steps were preparation of standard solutions, determination of $\lambda_{\max }$ and $\lambda_{\text {zero-crossing, preparation of standard }}$ curve at each $\lambda_{\text {zero-crossing, made a series of }}$ concentration from standard solution, the validation of analytical method, and then salbutamol and guaifenesin in syrup were determinated.

Salbutamol standard solutions 1000 ppm was made by weighing accurately $0.01 \mathrm{~g}$ of salbutamol and dissolving it in ethanol $10 \mathrm{~mL}$. A diluted solution of 100 ppm was prepared by pipetting $1 \mathrm{~mL}$ of the solution and diluting it with $\mathrm{NaOH} 0.1 \mathrm{~N}$ into $10 \mathrm{~mL}$. Guaifenesin standard solution 1000 ppm was made by weighing accurately $0.01 \mathrm{~g}$ of guaifenesin and dissolved it in ethanol $10 \mathrm{~mL}$.

Determination of $\lambda_{\max }$ and $\lambda_{\text {zero-crossing }}$ of salbutamol and guaifenesin were obtained by deriving the absorbance of the normal spectra towards the wavelength $(\mathrm{dA} / \mathrm{d} \lambda)^{7}$

Salbutamol and guaifenesin standard curves were obtained by measure $(\mathrm{dA} / \mathrm{d} \lambda)$ of the series of standard solutions at $\lambda_{\text {zero- }}$ crossing of the other compounds. ${ }^{7}$ Linear regression equations were calculated.

The concentration series of salbutamol standard solution were $0.2 ; 0.4 ; 0.6 ; 0.8$; $1.0 ; 1.2$; and $1.4 \mathrm{ppm}$. It was made from salbutamol standard solution $1000 \mathrm{ppm}$. The series concentrations of guaifenesin standard solution were $9,18,27,36,45$, 54 , and $63 \mathrm{ppm}$. The series concentrations were made from standard solution of guaifenesin $1000 \mathrm{ppm}$.

Table 1 Identification of Salbutamol and Guaifenesin ${ }^{6}$

\begin{tabular}{|c|c|c|c|c|}
\hline \multirow{2}{*}{ Parameter } & \multicolumn{2}{|c|}{ Salbutamol } & \multicolumn{2}{|l|}{ Guaifenesin } \\
\hline & Reference & Result & Reference & Result \\
\hline $\begin{array}{l}\text { Physical } \\
\text { appearance }\end{array}$ & $\begin{array}{l}\text { White crystalline } \\
\text { powder }\end{array}$ & $\begin{array}{l}\text { White crystalline } \\
\text { powder }\end{array}$ & White crystalline powder & $\begin{array}{l}\text { White crystalline } \\
\text { powder }\end{array}$ \\
\hline Solubility & $\begin{array}{l}\text { Slightly soluble in } \\
\text { water, soluble in } \\
\text { ethanol }\end{array}$ & $\begin{array}{l}\text { Slightly soluble in } \\
\text { water, soluble in } \\
\text { ethanol }\end{array}$ & $\begin{array}{l}\text { Soluble in water, ethanol and } \\
\text { chloroform }\end{array}$ & $\begin{array}{l}\text { Soluble in water, } \\
\text { ethanol and } \\
\text { chloroform }\end{array}$ \\
\hline Identification & $\begin{array}{l}\mathrm{UV} \text { absorbance in } \\
\mathrm{HCl} 0.1 \mathrm{~N} \text { shows } \\
\text { maximum as given } \\
\text { by salbutamol BPFI }\end{array}$ & $\begin{array}{l}\text { Fulfilled } \\
\text { requirement }\end{array}$ & $\begin{array}{l}\text { UV absorbance in chloroform } \\
\text { shows maximum as given by } \\
\text { guaifenesin BPFI }\end{array}$ & $\begin{array}{l}\text { Fulfilled the } \\
\text { requirement }\end{array}$ \\
\hline
\end{tabular}




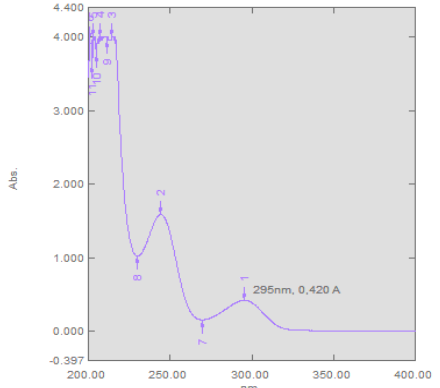

(a)

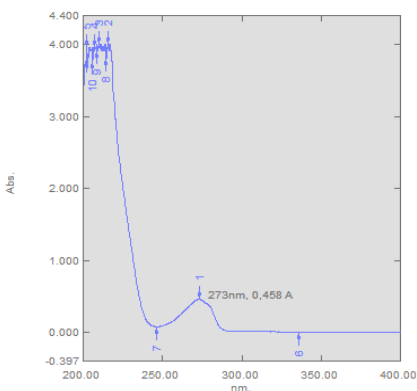

(b)

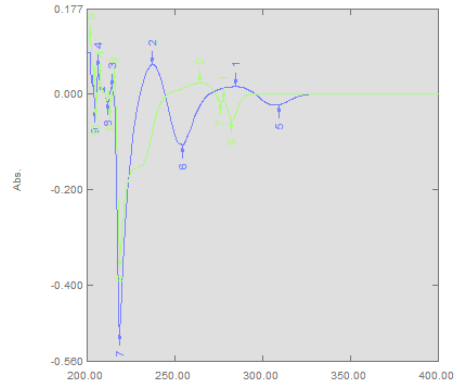

(c)

Figure 1 UV Spectrum of Salbutamol (a) and Guaifenesin (b), UV First Derivative Spectrum of Salbutamol (Blue) and Guaifenesin (Yellow) (c)

salbutamol and guaifenesin $(80 \%, 100 \%$, $120 \%)^{9}$ then dissolved into sugar solution. All concentrations of each compound were calculated using linear regression equation to obtain accuracy and precision. LOD and LOQ were calculated by measuring the absorbance of blank solution. ${ }^{8}$

Salbutamol and guaifenesin in syrup were determined by weighing accurately mixture of salbutamol (4 ppm), guaifenesin (18 ppm), and syrup then measured its absorbance at $\lambda_{\text {zero-crossing. }}$

\section{Results}

Salbutamol and guaifenesin were analyzed by according to Indonesian Pharmacope $5^{\text {th }}$ edition. Table 1 shows the result of salbutamol identification. ${ }^{6}$

Ultraviolet spectrum of salbutamol and guaifenesin are showed in Figure 1a and 1b. The first derivative spectrum of salbutamol and guaiafenesin showed in Figure 1c. Salbutamol and guaifenesin standard curve were obtained by measuring $(\mathrm{dA} / \mathrm{d} \lambda)$ of the series of standard solutions at $\lambda_{\text {zero-crossing }}$ of the other compounds. The calibration curve of salbutamol and guaifenesin showed in Table 3.

\section{Discussions}

Salbutamol shows maxima at $295 \mathrm{~nm}$ in $\mathrm{NaOH}^{4}(\mathrm{~A}=0.420)$, while guaifenesin is at $273 \mathrm{~nm}^{5}(\mathrm{~A}=0.458)$ (Figure 1a and $\left.1 \mathrm{~b}\right)$. Zero-crossing wavelength of salbutamol is $246.2 \mathrm{~nm}$ and guaifenesin is $270.2 \mathrm{~nm}$ (Figure 1c).

Linearity of the calibration curves (Table 3 and 4 ) is presented by the linear regression equation and coefficient of correlation $(\mathrm{r}){ }^{8}$ Linear regression of salbutamol is $\mathrm{y}=0.219 \mathrm{x}+0.006 \quad(\mathrm{r}=0.993)$, while for salbutamol is $\mathrm{y}=0.012 \mathrm{x}+0.022$ $(\mathrm{r}=0.997)$. Results of salbutamol and guaifenesin analysis are written in Table 5. Accuracy of the method was determined by calculating $\%$ recovery $^{8}$ and the result was 95.96\% (salbutamol) and 93.94\% (guaifenesin).

The method precision was determined

Table 3 Calibration Curve of Salbutamol and Guaienesin

\begin{tabular}{cccc}
\hline $\begin{array}{c}\text { Concentration of } \\
\text { salbutamol }(\mathrm{mg} / \mathrm{L})\end{array}$ & $\begin{array}{c}\text { Absorbance of } \\
\text { salbutamol } \\
(\mathrm{X})\end{array}$ & $\begin{array}{c}\text { Concentration of } \\
\text { guaifenesin }(\mathrm{mg} / \mathrm{L})\end{array}$ & $\begin{array}{c}\text { Absorbance of } \\
\text { guaifenesin } \\
(\mathrm{X})\end{array}$ \\
\hline 0.2 & 0.050 & 9 & 0.119 \\
0.4 & 0.099 & 18 & 0.264 \\
0.6 & 0.138 & 27 & 0.365 \\
0.8 & 0.181 & 36 & 0.458 \\
1.0 & 0.217 & 45 & 0.591 \\
1.2 & 0.259 & 54 & 0.700 \\
1.4 & 0.326 & 63 & 0.798 \\
\hline
\end{tabular}


Table 4 Analysis of Salbutamol and Guaifenesin in Syrup

\begin{tabular}{lcc}
\hline \multicolumn{1}{c}{ Parameters } & Salbutamol & Guaifenesin \\
\hline $\begin{array}{l}\text { Concentration } \\
(\mathrm{mg} / \mathrm{mL})\end{array}$ & 2.3059 & 91.238 \\
Recovery (\%) & 95.96 & 93.94 \\
Error (\%) & 1.69 & 1.27 \\
\hline
\end{tabular}

by calculating coefficient of variance ${ }^{8}$ and the result was $0.995 \%$ for salbutamol and $0.2087 \%$ for guaifenesin.

\section{Conclusions}

Zero-crossing derivative method could be applied to determine salbutamol and guaifenesin in mixture. Limit of detection of salbutamol and guaifenesin are 0.05528 ppm and 9.443 ppm, respectively, while limit of quantification are $0.18427 \mathrm{ppm}$ and $31.477 \mathrm{ppm}$.

\section{References}

1. Rajput SJ, Raj HA. Simultaneous spectroscopic estimation of ezetimibe and simvastatin in tablet dosage forms. Indian J Pharm Sci. 2007;69(6): 62-759.

2. Patel AH, Patel JK, Patel KN, Rajput GC, Rajgor NB. Development and validation of derivative spectrophotometric method for simultaneous estimation of domperidone and rabeprazole sodium in bulk and dosage forms. International Journal on Pharmaceutical and Biological Research. 2010;1(1):1-5.

3. Zambare YB, Santosh RK, Simpi CC. Simultaneous estimation of atorvastatin and ramipril by first derivative spectrophotometric method. Journal of
Pharmacy Research. 2009;2(5):874877.

4. Setiadi NR, Arifin MF, Ade RF. Pengaruh etanol $96 \%$ terhadap difusi salbutamol sulfat dalam sediaan transdermal sistem matriks kombinasi povidon-etilselulosa melalui membran millipore-isopropil miristat. Farmasains. 2011;1(4):156-164.

5. Bhattacharyya I, Bhattacharyya SP, Kyal C, Choudhury P, Dhakal B, Ghosh SK. Estimation and validation of stability indicating UV spectrophotometric method for the determination of guaifenesin In presence of its degradant products. International Journal of Pharmacy and Pharmaceutical Sciences. 2013;5(1): 262-268.

6. Kementrian Kesehatan Republik Indonesia. Farmakope Indonesia Edisi ke-5 Buku II. Jakarta: Kementerian Kesehatan Republik Indonesia; 2013.

7. Nilesh KM, Pawar HA, Vijaya C. "Zero-Crossing" first-order derivative spectroscopy method for analysis of sertraline hydrochloride in novel self micro emulsifying drug delivery system. Austin J Anal Pharm Chem. 2014;1(3):1013-1020.

8. Harmita. Petunjuk pelaksanaan validasi metode dan cara perhitungannya. Majalah Ilmu Kefarmasian. Desember 2004;1(3):117-135

9. Nagamalleswari G, Phaneemdra D, Prabakar AE, Suresh PV, Ramarao N. New colorimetric method development and validation of sulfacetamide in bulk and formulation by different analytical reagents. International Journal of Advances in Pharmaceutical Analysis (IJAPA). 2013;3(2):30-36. 